\title{
Pengaruh Kepemimpinan Dan Pengembangan Karir Terhadap Komitmen Karyawan PT Khalifa International Business Di Jakarta
}

\author{
M. Irfan Nawawi * \\ Aryanda** \\ *Universitas Jayabaya \\ **Universitas Jayabaya
}

\begin{tabular}{l} 
ARTICLE INFO \\
\hline Keywords: \\
Leadership, career development \\
employee commitment
\end{tabular}

Corresponding Author: nawawi676@yahoo.com

Manajerial

Volume 9 Nomor 2

November 2015 -April 2016

ISSN 2477-1376

hh. $65-70$ ABSTRACT

The purposed of this research was to identified the effect of leadership and career development partially and simultaneously on employee commitment PT Khalifa International Business in Jakarta. Research conducted on 21 employees of PT Khalifa International Business, data processing using analysis Regression. It is showed positive effect leadership and career development on employee commitment partially and simultaneously. With this research explicitly illustrated and analyzed the effect of leadership and career development on employee commitment including how the relationship between variables.

Penelitian ini bertujuan mengidentifikasi pengaruh kepemimpinan dan pengembangan karir secara parsial dan simultan pada komitmen karyawan PT Khalifa International Bussiness di Jakarta. Penelitian yang dilakukan pada 21 karyawan PT Khalifa International Bussiness, pengolahan data menggunakan analisis regresi. Penelitian ini menunjukkan kepemimpinan dan pengembangan karir berpengaruh positif terhadap komitmen karyawan secara parsial dan simultan. Penelitian ini secara eksplisit menggambarkan dan menganalisis pengaruh kepemimpinan dan pengembangan karir terhadap komitmen karyawan termasuk bagaimana hubungan antara variabel. 


\section{Pendahuluan}

Komitmen dan dedikasi karyawan terhadap organisasi akan memengaruhi besar kecilnya organisasi, jika terlalu sering terjadinya turnover karyawan yang sangat tinggi tentunya ini akan menimbulkan kerugian yang besar untuk organisasi, karena tidak dapat mempertahankan sumber daya manusia (SDM) mereka. Hal ini merupakan kerugian untuk organisasi karena tidak mudah untuk mencari SDM yang mempunyai kompetensi dan pengalaman, kalaupun ada maka "harga"mereka akan sangat tinggi di pasaran tenaga kerja.

Belakangan ini perusahaan berusaha membuat para karyawan yang bekerja agar mempunyai loyalitas tinggi, selain itu juga diharapkan tidak berpikir ulang mencari perusahaan yang lebih baik. Maka dibuatlah sebuah sistem non finansial yang berupaya menjaga loyalitas karyawan sehingga seminimal mungkin melakukan turnover. Luthans (2011) mendefinisikan komitmen organisasi sebagai sikap yang merefleksikan loyalitas karyawan kepada organisasi dan merupakan suatu proses berkelanjutan dimana anggota organisasi mengungkapkan perhatian mereka terhadap keberhasilan dan kemajuan organisasi yang berkelanjutan.

Klein, Molloy dan Brinsfield (2012) menyebutkan bahwa ciri-ciri yang dapat memengaruhi orang untuk membentuk ikatan komitmen yaitu kesadaran, ekstraversi, prestasi, afiliasi dan kebutuhan otonomi, penghindaran risiko dan kesediaan diri sendiri terhadap tujuan organisasi. Sedangkan menurut Nusair, Parsa dan Cobanoglu (2011) komitmen ditandai oleh tiga unsur: (a) kemauan untuk mengerahkan usaha yang cukup atas nama organisasi; (b) keyakinan yang kuat dalam tujuan dan nilai-nilai organisasi dan; (c) keinginan yang kuat untuk melanjutkan hubungan dengan organisasi.

Komitmen karyawan terhadap organisasi memiliki tiga aspek yaitu identifikasi, keterlibatan dan loyalitas karyawan terhadap organisasi, terutama untuk keterlibatan sangat diterima bagi para peneliti perilaku organisasi (Xu dan Cooper-Thomas, 2011). Mayer, Stanley, dan Parfyonova (2012) memberikan bentuk komitmen karyawan pada organisasi yang menjadi komitmen afektif, komitmen berkesinambungan dan komitmen normatif. Mayer et al. (2012) menambahkan bahwa kepuasan kebutuhan sebagai dasar terhadap pola pikir komitmen yang memiliki implikasi untuk memahami perkembangan komitmen. Misalnya, kepemimpinan transformasional. Hal ini menunjukkan bahwa kepuasan kebutuhan menjadi mekanisme penting yang terlibat dalam pengembangan komitmen karyawan dan pola pikir keharusan moral.

Kepemimpinan dalam organisasi merupakan hal yang sangat penting. Pemimpin dengan kelebihan dalam planing, organizing, actuating serta controlling memiliki kekuatan mencapai tujuan organisasi. Kepemimpinan adalah suatu cara untuk dapat mencapai tujuan organisasi, tanpa kepemimpinan yang efektif, arah dan tujuan organisasi akan nampak tidak jelas (Andersen, 2006). Kepemimpinan bertumpu pada komitmen mengimplementasikan konsep kepemimpinan dalam tindakan mencapai tujuan komunitas, bukan hanya tujuan pribadi. Pemimpin diberikan kebebasan yang sangat besar untuk mengembangkan potensi diri dan komunitasnya.

Pemimpin juga bekerja sama pada komunitas mereka dalam mencapai misi. Pemimpin mengembangkan kepercayaan pada orang lain untuk menjadikan kepemimpinan secara bersama, hal ini sangat efektif terhadap dua hal penting di dalam organisasi yaitu tindakan dan tanggung jawab (Raelin, 2005). Era globalisasi dan industrialisasi meningkatkan kompetensi dalam bidang karyawan. Seperti mempertahankan kualitas dan kuantitas karyawan. Lebih terarah lagi jika perusahaan berusaha meningkatkan apa yang sudah ada menjadi lebih baik sehingga dapat bersaing dengan perusahaan-perusahaan yang menjadi kompetitor. Fokus pada pelanggan juga mulai diterapkan dari perusahaan kepada karyawan dengan konsep perusahaan modern yaitu karyawan sebagai aset yang sangat berharga (Civi, 2000).

Selain itu juga ada perusahaan yang mulai melihat karyawannya sebagai konsumer internal, karena pasar utama bagi perusahaan adalah karyawan yang dapat menjadi business partner, hal ini dilihat dari perusahaan yang menanamkan sebuah brand image kepada karyawan, sehingga dapat tercipta harmonisasi dan perusahaan akan diuntungkan dengan adanya internal konsumer (Mohr-Jackson, 1991; Conduit dan Mavondo, 2001). Pengembangan dan pelatihan dalam suatu perusahaan dibutuhkan, bukan hanya untuk mempersiapkan kompetensi karyawan tetapi juga dalam memenuhi kekurangan pengetahuan karyawan sehingga akan memperkecil atau bahkan mencukupi pengetahuan yang dibutuhkan (Noe, 2010).

Pengembangan karir merupakan pendekatan secara formal yang dilakukan oleh organisasi untuk menjamin orang-orang yang berada dalam organisasi mempunyai kualifikasi dan kemampuan serta pengalaman yang cocok ketika dibutuhkan (Arms- 
trong dan Taylor, 2014). Hal ini dilakukan sebagai pengelolaan aset, serta pengembangan karir yang terstruktur akan meningkatkan efektivitas serta kreatifitas SDM (Zhou, Zhang dan Montoro-Sanchez, 2011) dan menumbuhkan komitmen terhadap organisasi dalam mencapai tujuannya (Porfeli dan Savickas, 2012).

Karyawan yang memiliki kesempatan dalam meningkatkan karirnya akan merangsang motivasinya untuk bekerja lebih baik (Bertolino, Truxillo dan Fraccaroli, 2011), sehingga perusahaan harus mempunyai model sistematis dalam melakukan pengembangan karir karyawannya (Hoekstra, 2011). Hasil penelitian tersebut juga didukung oleh Van Vianen, Dalhoeven dan De Pater (2001) bahwa perusahaan yang mempunyai manajemen karir yang baik akan meningkatkan kemauan karyawan berpartisipasi dalam aktivitas pengembangan dan perilaku dan hal tersebut akan meningkatkan kinerjanya

\section{Metodologi Penelitian}

Metode yang digunakan dalam penelitian ini adalah metode survei dengan teknik studi korelasional. Menurut Mertens (2010) riset korelasi (corelational study) merupakan penelitian yang dirancang untuk menentukan tingkat hubungan variabel-varia- bel yang berbeda dalam suatu populasi. Penelitian dengan survei dilakukan pada masalah yang lebih spesifik yang berkaitan dengan kepemimpinan dan pengembangan karir di manajemen PT Khalifa International Bussiness terhadap komitmen karyawan.

Berdasarkan informasi yang dikumpulkan pada survei tersebut, dilakukan proses pengolahan data dan analisa dengan menggunakan tehnik korelasi ganda dan analisis regresi berganda untuk mendapatkan jawaban yang sesuai dengan penelitian. Teknik pengumpulan data dalam penelitian terdiri dari kuesioner. Adapun prosedur penarikan sampel pada penelitian menggunakan metode random sampling, dengan menggunakan rumus Slovin (Sekaran, 2008).

\section{Hasil dan Pembahasan}

\section{Uji Asumsi Normalitas}

Hasil dari uji normalitas bertujuan untuk menguji apakah dalam model regresi mempunyai distribusi sebaran normal atau tidak, analisis tersebut menggunakan Uji Kolgomorov-Smirnov.

Tabel 1. Hasil Pengujian Asumsi Normalitas

\begin{tabular}{lcc}
\hline \multicolumn{1}{c}{ Variabel } & Kolmogorov-Smirnov Z & Asymp. Sig. (2-tailed) \\
\hline Komitmen & 0.547 & 0.926 \\
Karir & 0.881 & 0.419 \\
Kepemimpinan & 0.647 & $0 . .796$ \\
\hline
\end{tabular}

Berdasarkan tabel uji asumsi normalitas terlihat bahwa nilai $\mathrm{Z}$ untuk variabel kepemimpinan, karir dan komitmen karyawan memiliki nilai signifikansi $>0,01$, yang berarti ketiga variabel tersebut berdistribusi normal.

\section{Uji Asumsi Multikolinearitas}

Uji Multikolinearitas bertujuan untuk menguji apakah model regresi di temukan adanya korelasi yang sempurna antar variabel bebas (independen). Model regresi yang baik seharusnya tidak terjadi korelasi yang sempurna diantara variabel bebas. Salah satu cara untuk mendeteksi adanya multikoliniearitas adalah dengan melihat tolerance atau Varians Inflation Factor (VIF). Jika nilai tolerance $<0,10$ atau $=$ nilai VIF $>10$ berarti menunjukkan adanya multikolinearitas (Konishi, 2014)

Tabel 2. Hasil Uji Asumsi Multikolinearitas

\begin{tabular}{lcc}
\hline \multirow{2}{*}{ Variabel } & \multicolumn{2}{c}{ Collinearity Statistic } \\
\cline { 2 - 3 } & Tolerance & VIF \\
\hline Karir & 0.525 & 1.906 \\
Kepemimpinan & 0.525 & 1.906 \\
\hline
\end{tabular}

Dari tabel di atas diketahui, Berdasarkan hasil pengujian tidak terdapat variabel yang memiliki nilai VIF lebih besar dari 10 dan nilai tolerance yang lebih kecil dari $10 \%$, yang berarti bahwa tidak terdapat korelasi antar variabel bebas yang lebih besar dari 95\%. Maka dari hal itu dinyatakan tidak terdapat multikolinearitas antarvariabel bebas dalam model regresi. 


\section{Uji Asumsi Heteroskedastisitas}

Uji heteroskedisitas berguna untuk menguji apakah dalam model regresi tidak terjadi kesamaan variance dari residual satu pengamatan ke pengamatan yang lain (Konishi, 2014). Deteksi adanya hetero- skedatisitas apabila titik-titik yang ada membentuk suatu pola tertentu yang teratur terdapat heteroskedastisitas. Jika tidak terdapat pola yang jelas, serta titik-titik menyebar diatas dan dibawah angka nol pada sumbu Y, maka tidak terjadi heteroskedisitas.

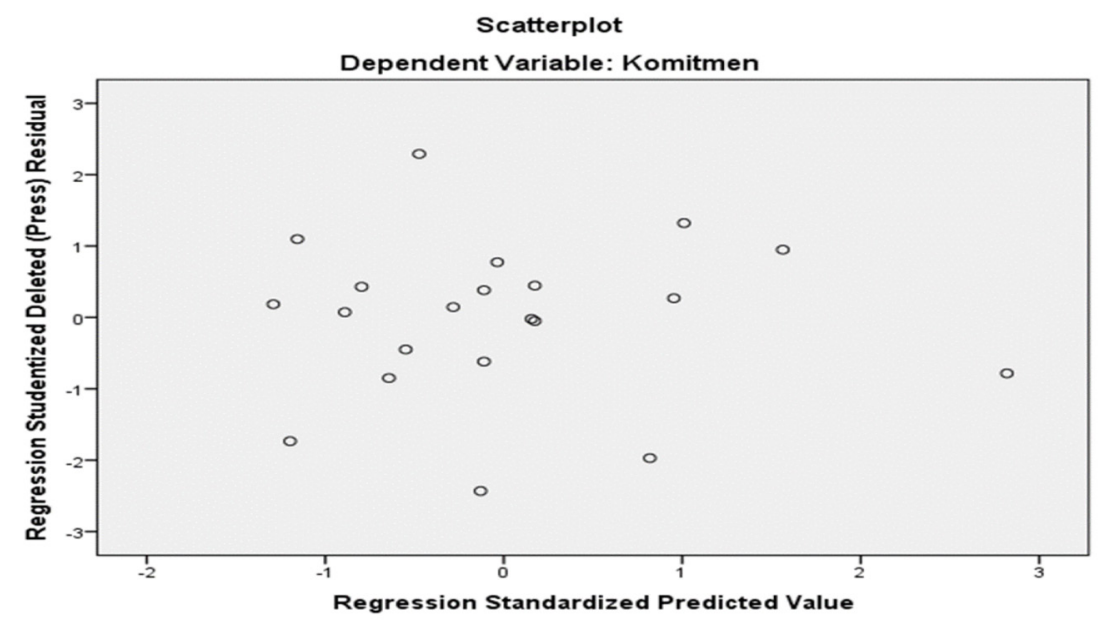

Gambar 1. Uji Asumsi Heteroskedastisitas

Berdasarkan hasil pada gambar di atas, tidak terdapat pola yang jelas, serta titik-titik menyebar di atas dan di bawah angka nol pada sumbu $Y$, dengan demikian tidak terjadi heteroskedastisitas.

\section{Pengujian Hipotesis}

\section{Uji Korelasi}

Uji korelasi bertujuan untuk mengetahui seberapa besar hubungan antara variabel kepemimpinan dan variable pengembangan karir dengan variabel komitmen karyawan yang terlihat pada tabel berikut

Tabel 3. Hasil Uji Korelasi

\begin{tabular}{ccc}
\hline Model & $\mathbf{R}$ & R-Square \\
\hline 1 & 0.864 & 0.715 \\
\hline
\end{tabular}

Dari perhitungan tabel di atas, hasil pengolahan data didapat nilai $R=0,846$, dan nilai $R$-Square sebesar 0,715 yang artinya terdapat hubungan yang erat antara kepemimpinan dan pengembangan karir dengan komitmen karyawan. Selanjutnya variabel kepemimpinan dan pengembangan karir memberikan kontribusi terhadap komitmen karyawan sebesar $71,5 \%$ (R-Square $=0,715$ ) sedangkan $28,5 \%$ lagi dipe- ngaruhi oleh faktor lain yang tidak dibahas dalam penelitian ini.

\section{UJI F}

Uji F digunakan untuk melihat apakah kepemimpinan (X1) dan pengembangan karir (X2) secara bersama-sama memiliki pengaruh yang signifikan terhadap komitmen karyawan.

Tabel 4. Hasil Uji Signifikan (Uji F)

\begin{tabular}{ccc}
\hline Model & F & Sig. \\
\hline 1 & 0.864 & 0.715 \\
\hline
\end{tabular}

Berdasarkan hasil uji F di dapat nilai F hitung sebesar 22,607 dengan nilai P (signifikan) sebesar 0,000 (taraf signifikansi 0,01 dari jumlah 21 responden (n1) $n=20$ responden, maka nilai $t$ table $=2,845)$ dikarenakan nilai F-hitung $>$ F-tabel dan nilai $\mathrm{P}<0,01$ maka dapat disimpulkan terdapat pengaruh yang signifikan secara bersama antara variabel kepemimpinan dan pengembangan karir terhadap komitmen karyawan.

\section{Uji Regresi Linier Berganda}

Tabel 5. Uji Regresi Linier Berganda

\begin{tabular}{lccc}
\hline \multicolumn{1}{c}{ Model } & $\beta$ & $\mathbf{t}_{\text {hitung }}$ & Sig. \\
\hline Constant & 16.687 & 2.543 & 0.000 \\
Kepemimpinan & .570 & 3.468 & \\
Pengembangan Karir & .696 & 4.536 & \\
\hline
\end{tabular}


Hasil pengolahan data menggunakan analisis regresi linier berganda didapat persamaan regresi berganda $Y=16,687+0,570 X 1+0,696 \times 2$ hal ini menunjukkan adanya pengaruh pengembangan karir terhadap komitmen karyawan. Berdasarkan hasil persamaan tersebut dapat di artikan, nilai a $=16,687$ yang artinya adalah jika ada dari variabel kepemimpinan dan pengembangan karir memiliki nilai 0, maka nilai komitmen karyawan PT Khalifa International Bussiness sebesar 16. 687, di dapat nilai $\mathrm{X} 1=0,570$ yang berarti setiap ada kenaikan dari nilai kepemimpinan satu kali, maka akan diikuti dengan peningkatan komitmen karyawan sebesar 0,570 . Sementara variabel pengembangan karir di dapat nilai $\mathrm{X} 2=0,696$ yang artinya setiap kenaikan dari nilai pengembangan karir, maka akan diikuti dengan peningkatan komitmen karyawan sebesar $=$ 0,696 .

\section{Kesimpulan}

Kepemimpinan dan pengembangan karir memiliki pengaruh terhadap komitmen karyawan, sedang-

\section{REFERENSI}

Armstrong, M., and Taylor, S. (2014). Armstrong's handbook of human resource management practice. London: Kogan Page.

Andersen, J. A. (2006). Leadership, personality and effectiveness. The Journal of Socio-Economics, Vol. 35 No. 6, pp. 1078-1091.

Bertolino, M., Truxillo, D. M., and Fraccaroli, F. (2011). Age as moderator of the relationship of proactive personality with training motivation, perceived career development from training, and training behavioral intentions. Journal of Organizational Behavior, Vol. 32 No. 2, pp. 248-263.

Civi, E. (2000). Knowledge management as a competitive asset: A review. Marketing Intelligence E Planning, Vol. 18 No. 4, pp. 166-174.

Conduit, J., and Mavondo, F. T. (2001). How critical is internal customer orientation to market orientation? Journal of Business Research, Vol. 51 No. 1, pp. 11-24.

Creswell, J. W. (2014). Research Design: Qualitative, Quantitative, and Mixed Methods Approaches. California: SAGE Publications, Inc.

Hoekstra, H. A. (2011). A career roles model of career development. Journal of Vocational Behavior, Vol. 78 No. 2, pp. 159-173.

Klein, Howard J., Molloy, Janice C., and Brinsfield, Chad T. (2012). Reconceptualizing workplace commitment to redress a stretched construct: Revisiting assumptions and removing confounds. Academy of Management Review, Vol. 37 No. 1, pp. 130-151.

Konishi, S. (2014). Introduction to Multivariate Analysis Linear and Nonlinear Modeling. Florida: CRC Press.

Luthans, Fred. (2011). Organizational behavior: An evidence-based approach. New York: McGraw-Hill.

Mertens, D. M. (2010). Research and Evaluation in Education and Psychology: Integrating Diversity with Quantitative, Qualitative, and Mixed Methods. California: SAGE Publications, Inc.

Meyer, J. P., Stanley, L. J., and Parfyonova, N. M. (2012). Employee commitment in context: The nature and implication of commitment profiles. Journal of Vocational Behavior, Vol. 80 No. 1, pp. 1-16. 
Mohr-Jackson, Iris. (1991). Broadening the market orientation: An added focus on internal customers. Human Resource Management, Vol. 30 No. 4, pp. 455-467.

Noe, R. A. (2010). Employee training and development. New York: McGraw-Hill.

Nusair, Khaldoon "Khal", Parsa, H. G., and Cobanoglu, Cihan. (2011). Building a model of commitment for Generation Y: An empirical study on e-travel retailers. Tourism Management, Vol. 32 No. 4, pp. 833-843.

Porfeli, E. J., and Savickas, M. L. (2012). Career Adapt-Abilities Scale-USA Form: Psychometric properties and relation to vocational identity. Journal of Vocational Behavior, Vol. 80 No. 3, pp. 748-753.

Raelin, Joseph A. (2005). We the leaders: In order to form a leaderful organization. Journal of Leadership and Organizational Studies, 2005, Vol. 12 No. 2, pp. 18-30.

Sekaran, U. (2008). Research Methods for Business: A Skill-Building Approach. New York: John Wiley \& Sons, Inc.

Van Vianen, A., Dalhoeven, B. A., and De Pater, I. E. (2011). Aging and training and development willingness: Employee and supervisor mindsets. Journal of Organizational Behavior, Vol. 32 No. 2, pp. 226-247.

Xu, J., and Cooper-Thomas, H. (2011) How can leaders achieve high employee engagement? Leadership $\mathcal{E}$ Organization Development Journal, Vol. 32 No. 4, pp. 399-416.

Zhou, Y., Zhang, Y., and Montoro-Sanchez, A. (2011). Utilitarianism or romanticism: the effect of rewards on employees' innovative behaviour. International Journal of Manpower, Vol. 32 No. 1, pp. 81-98. 